(2) Open Access Full Text Article

REVIEW

\title{
Pleiotropic effects of the HMG-CoA reductase inhibitors
}

This article was published in the following Dove Press journal:

International Journal of General Medicine

| April 20 I I

Number of times this article has been viewed

\section{Christos G Mihos \\ Orlando Santana}

Columbia University Division of Cardiology, Mount Sinai Heart Institute, Miami Beach, FL, USA
Correspondence: Orlando Santana Mount Sinai Heart Institute, 4300 Alton Road, Miami Beach, FL 33140, USA

Tel +l 3056742 I 68

Fax +l 3056742368

Email osantana@msmc.com
Abstract: The HMG-CoA reductase inhibitors (statins) are used extensively in the treatment of hyperlipidemia. They have also demonstrated a benefit in a variety of other disease processes. These secondary actions are known as pleiotropic effects. Our paper serves as a focused and updated discussion on the pleiotropy of statins and emphasizes the importance of randomized placebo-controlled trials to further elucidate this interesting phenomenon.

Keywords: HMG-CoA inhibitors, pleiotropic, reductase, review, statins

\section{Introduction}

Statins are a mainstay in the treatment of hyperlipidemia and are used in the primary and secondary prevention of coronary artery disease. ${ }^{1,2}$ Recent studies have shown that statins also possess powerful pleiotropic effects that are independent of their cholesterollowering properties, a fact that has piqued the interest of the medical community.

The pleiotropic effects of statins are attributed to several processes resulting from the inhibition of HMG-CoA reductase. The main effect of statins is the inhibition of cholesterol and isoprenoid synthesis, which ultimately results in upregulation of endothelial nitric oxide synthase, an enzyme responsible for vascular endothelial function, and thus improved pathophysiologic response. ${ }^{3,4}$ Additionally, antioxidant effects via the decreased production of NADPH oxidase leads to decreased amounts of reactive oxidant species in the circulation. ${ }^{3}$ Inflammatory markers such as C-reactive protein and nuclear factor-k B have also been shown to be reduced by statins, leading to the hypothesis that statins possess anti-inflammatory properties. ${ }^{5}$ Other proposed mechanisms include immunomodulation, normalization of sympathetic outflow, plaque stabilization, decreased activation of the blood coagulation cascade, and inhibition of platelet aggregation (Table 1). ${ }^{6}$

A wide range of disease processes have been linked to better outcomes when patients are treated with statins (Table 2). The following is a review of the current literature and recent studies regarding the potential therapeutic benefits and pleiotropic effects of statins (Table 3).

\section{Cardiovascular disorders} Heart failure

Patients in the early or mild stages of heart failure have been shown to benefit from statins via their anti-inflammatory properties and enhancement of endothelial function. $^{7,8}$ The CORONA (Controlled Rosuvastatin Multinational Trial in Heart 
Table I Proposed mechanisms of statin pleiotropy

- Upregulation of endothelial nitric oxide synthase and improved pathophysiologic response, including inhibition of vasoconstriction and promotion of re-endothelialization

- Antioxidant effects via the inhibition of nicotinamide adenine dinucleotide phosphate oxidase and thus reactive oxidant species

- Anti-inflammatory properties, including reduction in C-reactive protein, interleukin 6, tumor necrosis factor alpha, and nuclear factor-k B levels

- Downregulation of cytokines and chemokines

- Stabilization of atherosclerotic plaques and inhibition of plaque inflammation

- Decreased activation of the blood coagulation cascade

- Inhibition of platelet aggregation

- Normalization of sympathetic tract outflow

- Induction of autophagy and inhibition of angiogenesis in cancer cells

- Neuroprotection and support of blood-brain barrier function

Failure) trial, ${ }^{9}$ a retrospective study of 5011 patients, concluded that those with high sensitivity $\mathrm{C}$-reactive protein $>2 \mathrm{mg} / \mathrm{L}$ receiving rosuvastatin $10 \mathrm{mg}$ daily had a reduced incidence of the primary outcome (cardiovascular death, myocardial infarction or stroke, $P=0.024$ ), coronary events

Table 2 Overview of statin pleiotropy and medical disorders

\begin{tabular}{|c|c|}
\hline System & Disorder \\
\hline \multirow[t]{6}{*}{ Cardiology } & Heart failure \\
\hline & Atrial fibrillation \\
\hline & Ventricular arrhythmias \\
\hline & Acute coronary syndrome and \\
\hline & percutaneous coronary intervention \\
\hline & Aortic stenosis \\
\hline \multirow[t]{2}{*}{ Pulmonology } & Asthma \\
\hline & Chronic obstructive lung disease \\
\hline \multirow[t]{5}{*}{ Hematology/oncology } & Prostate cancer \\
\hline & Colon cancer \\
\hline & Lung cancer \\
\hline & Pancreatic cancer \\
\hline & Renal cancer \\
\hline \multirow[t]{5}{*}{ Neurology } & Stroke \\
\hline & Intracranial hemorrhage \\
\hline & Multiple sclerosis \\
\hline & Alzheimer's disease \\
\hline & Parkinson's disease \\
\hline \multirow[t]{4}{*}{ Nephrology } & Glomerulonephritis \\
\hline & Renal failure \\
\hline & Renal transplantation \\
\hline & Contrast-induced nephropathy \\
\hline \multirow[t]{4}{*}{ Rheumatology } & Rheumatoid arthritis \\
\hline & Osteoarthritis \\
\hline & Osteoporosis \\
\hline & Systemic sclerosis \\
\hline \multirow[t]{5}{*}{ Miscellaneous } & Venous thromboembolism \\
\hline & Polycystic ovary syndrome \\
\hline & Macular degeneration \\
\hline & Influenza \\
\hline & Infection and sepsis \\
\hline
\end{tabular}

$(P=0.017)$, all-cause mortality or worsening heart failure $(P=0.017)$, and a decreased number of hospitalizations for cardiovascular reasons $(P<0.001)$ or worsening heart failure $(P=0.004)$ compared to placebo. The benefit of reduced incidence of cardiovascular hospitalization was also seen in a study by Kjeshkus et al ${ }^{10}$ of elderly systolic heart failure patients treated with rosuvastatin $(P=0.04)$.

\section{Atrial fibrillation}

Statins have been shown to prevent structural and electrical remodeling and blunt the development of atrial fibrillation in the setting of atrial tachycardia. ${ }^{11}$ Additionally, shortened intra-atrial conduction time, decreased duration of atrial fibrillation, and increased atrial effective refractory period have been shown to be the result of anti-inflammatory properties possessed by statins. ${ }^{12}$

Young-Xu et al ${ }^{13}$ prospectively evaluated 449 patients with stable coronary artery disease and no history of atrial fibrillation over five years, and found that statin users had a 59\% decreased risk of developing atrial fibrillation $(P<0.01)$. Meanwhile, Kulik et $\mathrm{al}^{14}$ assessed the incidence of newonset atrial fibrillation in 29,088 patients after myocardial infarction or coronary revascularization, and found a $10 \%$ reduced risk in statin-treated patients $(P=0.0006)$. Siu et al ${ }^{15}$ retrospectively studied 62 patients with lone persistent atrial fibrillation of at least three months' duration who underwent successful external electrical cardioversion, and showed that statin use was associated with a significantly decreased risk of recurrence of atrial fibrillation $(P=0.032)$.

The incidence and duration of atrial fibrillation is also decreased by statins in postoperative cardiac patients. In a cohort of 140 patients without prior atrial fibrillation or statin use undergoing elective coronary artery bypass grafting, the incidence of new-onset atrial fibrillation was 14\% versus 32\% for the control group $(P=0.009)$, with a mean duration of single atrial fibrillation of 3.6 hours versus 5.7 hours $(P<0.01)$ during the first seven postoperative days in those assigned to daily atorvastatin. ${ }^{16}$ Furthermore, a recent observational study using data from 64,679 patients enrolled in GRACE (Global Registry of Acute Coronary Events) ${ }^{17}$ showed that statin users hospitalized for acute coronary syndrome were not only at lower risk of developing inhospital atrial fibrillation $(P<0.0001)$, but also had a significantly decreased risk of developing ventricular arrhythmias, cardiac arrest, and/or death.

\section{Ventricular arrhythmias}

Studies have shown a correlation between statin use and a decreased incidence of ventricular arrhythmias or 
Table 3 Major trials and studies exhibiting statin pleiotropy

\begin{tabular}{|c|c|c|}
\hline Trial/study & Design & Outcomes with statin treatment \\
\hline $\begin{array}{l}\text { Controlled Rosuvastatin Multinational } \\
\text { Trial in Heart Failure (CORONA })^{7,9}\end{array}$ & $\begin{array}{l}50 \text { I I patients with heart failure, } \\
\text { reduced left ventricular function, and } \\
\text { ischemic heart disease randomly assigned } \\
\text { to } 10 \mathrm{mg} / \text { day rosuvastatin or placebo }\end{array}$ & $\begin{array}{l}\text { Patients with NT-proBNP }<103 \text { pmol/L had } 35 \% \\
\text { reduction in atherothrombotic events or sudden death } \\
\text { Patients with hs-CRP }>2 \mathrm{mg} / \mathrm{L} \text { had better outcomes, } \\
\text { decreased all-cause mortality and coronary events, less } \\
\text { hospitalizations }\end{array}$ \\
\hline $\begin{array}{l}\text { Global Registry of Acute Coronary } \\
\text { Events (GRACE) })^{17}\end{array}$ & $\begin{array}{l}64,679 \text { patients hospitalized for ACS } \\
\text { in 1999-2007 were prospectively analyzed } \\
\text { in an observational study }\end{array}$ & $\begin{array}{l}\text { Patients taking statins prior to hospital admission had } \\
\text { a significantly lower risk of atrial fibrillation, VT/VF, } \\
\text { cardiac arrest, and death }\end{array}$ \\
\hline $\begin{array}{l}\text { Multicenter Automatic Defibrillator } \\
\text { Implantation Trial II (MADIT-II) }\end{array}$ & $\begin{array}{l}654 \text { patients receiving an ICD were } \\
\text { analyzed based on the percentage of }\end{array}$ & $\begin{array}{l}\geq 90 \% \text { statin usage was associated with a reduced risk } \\
\text { of VT/VF or cardiac death }\end{array}$ \\
\hline
\end{tabular}

Efficacy of high-dose atorvastatin loading before primary percutaneous coronary intervention in ST-segment elevation myocardial infarction: The STATIN STEMI trial ${ }^{20}$

Atorvastatin for Reduction of

Myocardial Damage during

Angioplasty trial (ARMYDA) ${ }^{21}$

Pravastatin or Atorvastatin Evaluation and Infection Therapy-Thrombolysis

In Myocardial Infarction 22 trial

(PROVE IT-TIMI 22) ${ }^{24}$

Pravastatin or Atorvastatin Evaluation and Infection Therapy-Thrombolysis In Myocardial Infarction 22 [PROVE IT-TIMI 22] Substudy (PCI-PROVE IT) ${ }^{25}$

Efficacy of atorvastatin reload in patients on chronic statin therapy undergoing percutaneous coronary intervention: results of the ARMYDA-RECAPTURE randomized trial ${ }^{26}$

Justification for the Use of statins in Prevention: an Intervention Trial Evaluating Rosuvastatin (JUPITER) ${ }^{50}$ days statins were taken during follow-up I7I STEMI patients randomized to $600 \mathrm{mg}$ Plavix $^{\circledR}$ plus either $80 \mathrm{mg}$ or $10 \mathrm{mg}$ atorvastatin pre- $\mathrm{PCl}$, with all patients treated with $10 \mathrm{mg}$ atorvastatin post-PCI

I53 statin-naïve patients with chronic stable angina undergoing elective $\mathrm{PCl}$ randomized to atorvastatin or placebo seven days prior to intervention

3745 ACS patients randomized to either $40 \mathrm{mg}$ pravastatin or $80 \mathrm{mg}$ atorvastatin daily

2868 ACS patients who underwent $\mathrm{PCl}$ prior to enrollment in PROVE IT-TIMI 22, which randomized patients to $80 \mathrm{mg}$ atorvastatin or $40 \mathrm{mg}$ pravastatin daily

383 long-term statin users with stable angina or NSTEMI undergoing $\mathrm{PCl}$ were randomized to atorvastatin reload or placebo pre- $\mathrm{PCl}$, with all patients treated with atorvastatin post-PCl

I 7,802 patients with normal LDL-C and elevated CRP randomly assigned to $20 \mathrm{mg} /$ day rosuvastatin or placebo
High-dose atorvastatin pre-PCl was associated with immediate improvement of coronary flow and microvascular myocardial perfusion when compared with low-dose atorvastatin

Significant reduction in procedural myocardial injury

High-dose statin therapy superior in aggressive reduction of both LDL-C and CRP levels, leading to lower risk of recurrent myocardial infarction or vascular death

Reduction in major adverse cardiovascular events, as well as target and nontarget vessel revascularization with intensive statin therapy

Decreased 30-day incidence of major adverse cardiovascular events, as well as postprocedural myocardial injury, in patients receiving high-dose pre- $\mathrm{PCl}$ atorvastatin reload

Reduced the incidence of stroke by more than $50 \%$; reduction in nonfatal $\mathrm{MI}$ and cardiovascular death

Abbreviations: NT-proBNP, N-terminal fragment brain natriuretic peptide; hs-CRP, high-sensitivity C-reactive protein; ACS, acute coronary syndrome; VT, ventricular tachycardia; VF, ventricular fibrillation; ICD, implantable cardioverter defibrillator; STEMI, ST-segment elevation myocardial infarction; PCl, percutaneous coronary intervention; LDL-C, low density lipoprotein cholesterol; NSTEMI, non-ST-segment elevation myocardial infarction; MI, myocardial infarction.

sudden cardiac death. Chiu et a ${ }^{18}$ assessed 281 patients with ischemic cardiomyopathy undergoing implantable cardioverter defibrillator placement with subsequent outpatient follow-up. Those who received statin therapy had a reduced incidence of ventricular arrhythmia requiring use of the defibrillator $(P=0.01)$. The MADIT-II (Multicenter Automatic Defibrillator Implantation Trial II) trial $^{19}$ looked at 654 patients with ischemic cardiomyopathy and implantable cardioverter defibrillator placement, and found a 35\% risk reduction for sudden cardiac death or development of ventricular arrhythmia in patients taking statins $(P<0.01)$. The results observed may be due to mechanisms similar to those seen in atrial fibrillation, with plaque stabilization also protecting against ischemia-induced arrhythmias.

\section{Percutaneous coronary intervention and acute coronary syndrome}

Statin pleiotropy in patients undergoing percutaneous coronary intervention has been well established. Via their ability to stabilize plaques and exert anti-inflammatory and antithrombotic properties, statins increase coronary blood flow and microvascular myocardial perfusion. ${ }^{20}$ The ARMYDA (Atorvastatin for Reduction of Myocardial Damage during Angioplasty) trial, ${ }^{21}$ which looked at 153 statin-naïve patients with stable angina undergoing elective percutaneous coronary 
intervention, found a significantly reduced risk of myocardial injury in patients assigned to $40 \mathrm{mg}$ of atorvastatin daily for seven days prior to percutaneous coronary intervention, with similar results reported in other randomized trials. ${ }^{22,23}$ Additionally, recent studies suggest an increased benefit with high-dose therapy as opposed to conservative regimens. ${ }^{24}$ Gibson et $\mathrm{al}^{25}$ assessed the incidence of the primary composite endpoint (all-cause mortality, myocardial infarction, unstable angina leading to hospitalization, 30-day revascularization, or stroke), target vessel revascularization, and nontarget vessel revascularization among 2868 patients undergoing percutaneous coronary intervention in the setting of acute coronary syndrome. Those treated daily with $80 \mathrm{mg}$ of atorvastatin had a decreased incidence of the primary composite endpoint $(21.5 \%$ versus $26.5 \%, P=0.002)$ and target vessel revascularization $(11.4 \%$ versus $15.4 \%, P=0.001)$ compared with patients treated with $40 \mathrm{mg}$ of pravastatin. Furthermore, patients on chronic statin therapy suffering from stable angina or acute non-ST-segment elevation myocardial infarction benefit from reloading with statins before percutaneous coronary intervention, having a 50\% reduced risk of major adverse cardiac events (cardiac death, myocardial infarction, or unplanned revascularization) after intervention $(P=0.039) .{ }^{26}$

\section{Aortic stenosis}

It has been postulated that the anti-inflammatory effects of statins may help in reducing the progression of aortic stenosis. A retrospective study ${ }^{27}$ of 174 patients with mild to moderate aortic stenosis, of whom 57 were on statins, demonstrated a decrease in the aortic valve area of $0.06 \mathrm{~cm}^{2} /$ year in the statin treatment group compared with $0.11 \mathrm{~cm}^{2} /$ year in the nonstatin group $(P=0.03)$ at the 21-month follow-up. Another retrospective study ${ }^{28}$ of 180 patients with mild aortic stenosis and on statin treatment showed a reduction in the increase in the peak systolic gradient across the aortic valve over three years $(P=0.009)$.

A four-year prospective trial by Bellamy et $\mathrm{al}^{29}$ of 156 patients taking either simvastatin or lovastatin demonstrated that statin users had a slower reduction of aortic valve area of $-0.04 \mathrm{~cm}^{2} /$ year versus $0.09 \mathrm{~cm}^{2} /$ year in the placebo group $(P<0.01)$. Another prospective study called RAAVE (Rosuvastatin Affecting Aortic Valve Endothelium) $)^{30}$ compared the effects of rosuvastatin versus placebo in 121 patients with moderate to severe asymptomatic aortic stenosis. At the 18-month follow-up, researchers found a decrease in aortic valve area of $0.05 \mathrm{~cm}^{2}$ in the rosuvastatin group, compared with $0.10 \mathrm{~cm}^{2}$ in the placebo group $(P=0.041$, Table 4$)$.
Table 4 Pleiotropic effects of statins in cardiovascular disorders

\begin{tabular}{|c|c|}
\hline Heart & $\begin{array}{l}\text { - } \downarrow \text { risk of coronary events and } \\
\text { cardiovascular death } \\
\text { - } \downarrow \text { all-cause mortality } \\
\text { - } \downarrow \text { hospitalizations for cardiovascular } \\
\text { reasons or worsening heart failure } \\
\text { - Prevent further decompensation of cardiac } \\
\text { function }\end{array}$ \\
\hline Atrial fibrillation ${ }^{13-17}$ & $\begin{array}{l}-\downarrow \text { duration of atrial fibrillation } \\
\text { - } 59 \% \downarrow \text { incidence in stable coronary artery } \\
\text { disease } \\
\text { - } 10 \% \downarrow \text { incidence after myocardial infarction } \\
\text { or coronary revascularization } \\
\text { - } \downarrow \text { recurrence after electric cardioversion } \\
\text { - } \downarrow \text { incidence after acute coronary syndrome } \\
\text { - } \downarrow \text { incidence and duration in postoperative } \\
\text { cardiac patients }\end{array}$ \\
\hline $\begin{array}{l}\text { Ventricular } \\
\text { arrhythmias } \\
18,19\end{array}$ & $\begin{array}{l}\text { - } \downarrow \text { incidence of ICD shocks and } 35 \% \\
\downarrow \text { risk of sudden cardiac death in patients } \\
\text { with ICD and ischemic cardiomyopathy }\end{array}$ \\
\hline $\begin{array}{l}\text { Percutaneous coronary } \\
\text { intervention and acute } \\
\text { coronary syndrome }{ }^{21-26}\end{array}$ & $\begin{array}{l}\text { - Significantly reduced risk of myocardial } \\
\text { injury in elective } \mathrm{PCl} \text { in statin-naïve patients } \\
\text { - } 50 \% \downarrow \text { risk of major adverse cardiac events } \\
\text { in statin users reloaded with statin prior } \\
\text { to } \mathrm{PCl} \\
\text { - Superior concomitant reduction in LDL-C } \\
\text { and CRP with high-dose statin therapy }\end{array}$ \\
\hline Aortic stenosi & $\begin{array}{l}\text { - Significantly slower reduction of AV area } \\
\text { - Slower increase of AV peak systolic gradient }\end{array}$ \\
\hline
\end{tabular}

Abbreviations: ICD, implantable cardioverter defibrillator; $\mathrm{PCl}$, percutaneous coronary intervention; LDL-C, low-density lipoprotein cholesterol; CRP, C-reactive protein; $\mathrm{AV}$, aortic valve.

\section{Pulmonary disorders}

\section{Asthma}

Statins may play a protective role in asthma patients by curbing inflammation and airway remodeling. A recent study $^{31}$ assessed 70 asthmatic patients at baseline and two months after beginning statin therapy. Researchers found a decrease in rescue inhaler use from nine to five times per week $(P<0.0001)$, increased peak flow from $301 \mathrm{~L} / \mathrm{min}$ two months prior to $335 \mathrm{~L} / \mathrm{min}$ two months after starting therapy $(P<0.0001)$, and an increase in patients classified as having "mild" disease, with a concurrent decrease in "moderate-to-severe" classifications. Additionally, studies have shown that adult asthmatics receiving statin therapy have a $30 \%$ risk reduction for hospitalizations and emergency department visits related to their disease $(P<0.001){ }^{32}$

\section{Chronic obstructive lung disease}

Blamoun et $\mathrm{al}^{33}$ retrospectively assessed the incidence of chronic obstructive pulmonary disease exacerbations and intubations in 185 statin users with established obstructive lung disease. At one year, patients not taking statins were 
more likely to have suffered an exacerbation $(P<0.0001)$ or have required intubation $(P<0.0001)$ compared with the treatment group. Statins have also been shown to decrease 90-day mortality in patients hospitalized with emphysematous exacerbations ${ }^{34}$ and are useful in preservation of lung function in elderly patients with a history of smoking. ${ }^{35,36}$

\section{Cancers}

\section{Prostate cancer}

Studies have shown that statins induce autophagy and cell death in prostate cancer cells while causing no hindrance to normal cells. ${ }^{37} \mathrm{~A}$ retrospective analysis of CaPSURE (Cancer of the Prostate Strategic Urologic Research Endeavor), ${ }^{38}$ which included 7042 men who underwent radical prostatectomy or radiotherapy for prostate cancer, showed a $65 \%$ reduction in all-cause mortality after radical prostatectomy and a $41 \%$ reduction after radiotherapy with concomitant use of statins. A second study demonstrated improved freedom from biochemical failure and salvage androgen deprivation therapy, as well as improved relapse-free survival rates in statin users who underwent radiotherapy. ${ }^{39}$ Furthermore, patients undergoing radical prostactectomy placed on preoperative simvastatin have a $69 \%$ reduced risk of intratumoral inflammation, a complication that may lead to prostate cancer progression..$^{40}$

\section{Colon cancer}

Studies have shown that statins inhibit the progression of colon cancer and attenuate tumor burden by inducing apoptosis, ${ }^{41-43}$ inhibiting angiogenesis, ${ }^{41}$ and decreasing the production of proinflammatory cytokines. A case-control study by Poynter et $\mathrm{al}^{44}$ found that patients treated with at least five years of statin therapy had a $50 \%$ reduced risk of colorectal cancer, adding to prior reports of lower rates of Stage IV carcinomas in statin users. ${ }^{45}$ Additionally, patients with a history of adenomatous colon polyps who were on statins had smaller polyp size, a reduced number of polyps, and reduced incidence of pathologic progression or recurrent polyps on 3-5-year colonoscopy follow-up, ${ }^{46}$ suggesting that statins may play a preventive role in the development of colorectal cancer.

\section{Lung, pancreatic, and renal cancer}

Khurana et al ${ }^{47-49}$ performed a series of retrospective nested case-control studies using the Veterans Affairs database. Patients who used statins for at least six months had a $55 \%$ $(P<0.01)$ decreased incidence of lung cancer and a $67 \%$ $(P<0.01)$ reduced risk of developing pancreatic cancer, while patients on statin therapy for longer than four years had an $80 \%(P<0.01)$ decreased risk in developing pancreatic cancer. The authors concluded that statins may also play a protective role in the development of renal cell carcinoma (Table 5).

\section{Neurological disorders Stroke and intracranial hemorrhage}

Statins have been shown to be beneficial in primary and secondary stroke prevention, ${ }^{50}$ preventing ischemia and hemorrhage by increasing cerebral vasomotor reactivity and decreasing vasospasm. ${ }^{51-53} \mathrm{~A}$ meta-analysis of randomized trials that included 165,792 patients found statin users to have a $21 \%$ reduced risk of stroke $(P=0.009)$, while patients with prior stroke had a $16 \%$ reduced risk of recurrence $(P=0.03) .{ }^{54}$ Similar effects have been observed in patients with intracranial hemorrhage. Naval et a ${ }^{55}$ retrospectively looked at 125 patients with intracranial hemorrhage unrelated to trauma or an underlying lesion. Statin use was associated with decreased mortality and a 12-fold increase in rate of survival $(P=0.05)$. Furthermore, a meta-analysis ${ }^{56}$ of randomized trials of patients with aneurysmal subarachnoid hemorrhage found that those who were started on statin therapy at the time of the event had a $27 \%$ reduced risk of vasospasm, a $62 \%$ reduction in delayed ischemic events, and an $82 \%$ reduction in mortality.

\section{Multiple sclerosis}

Statins have synergistic effects when used in combination with conventional multiple sclerosis drugs and may possess reparative properties. ${ }^{57,58}$ It is hypothesized that their ability to reduce the amount of lymphocytes and monocytes crossing the blood-brain barrier decreases the amount of perivascular infiltrates that fuel demyelination. ${ }^{59,60}$ Vollmer et al ${ }^{61}$ prospectively studied 30 patients with relapsing-remitting multiple sclerosis and reported a $44 \%$ decrease $(P<0.0001)$

Table 5 Pleiotropic effects of statins in malignancies

\begin{tabular}{|c|c|}
\hline Prostate cancer $r^{38-40}$ & $\begin{array}{l}\text { - } \downarrow \text { all-cause mortality } \\
\text { - } \uparrow \text { relapse-free survival } \\
\text { - } \downarrow \text { risk of intratumoral inflammation } \\
\text { - } \downarrow \text { biochemical failure and androgen deprivation } \\
\text { therapy }\end{array}$ \\
\hline Colon cancer ${ }^{44-46}$ & $\begin{array}{l}\text { - } 50 \% \downarrow \text { risk of colorectal cancer after } 5 \text { years } \\
\text { - } \downarrow \text { rate of stage IV carcinomas } \\
\text { - } \downarrow \text { colon polyp size, number, and progression rate }\end{array}$ \\
\hline Lung cancer ${ }^{47}$ & - $50 \% \downarrow$ incidence after 6 months of therapy \\
\hline Pancreatic cancer ${ }^{48}$ & $\begin{array}{l}\text { - } 67 \% \downarrow \text { incidence after } 6 \text { months, } 80 \% \downarrow \text { after } \\
\text { four years }\end{array}$ \\
\hline
\end{tabular}


in the number and a $41 \%$ decrease $(P<0.0018)$ in the volume of gadolinium-enhancing brain lesions after six months of treatment with $80 \mathrm{mg}$ of simvastatin daily. Paul et $\mathrm{al}^{62}$ verified these findings, showing that patients treated with high-dose atorvastatin had a significantly decreased number $(P<0.003)$ and size $(P<0.008)$ of lesions on magnetic resonance imaging after 6-9 months of therapy.

\section{Alzheimer's disease}

By impairing production of beta-amyloid proteins and apolipoprotein $\mathrm{E}$ and exerting anti-inflammatory effects, ${ }^{63}$ statins are proposed to decrease the amount of tau fibrillization in the pathophysiologic process of Alzheimer's disease ${ }^{64}$ A recent study by Li et a ${ }^{65}$ of 3099 elderly patients reported a 38\% reduction in development of Alzheimer's disease in those who began taking statins before the age of 80 years. A second study by Rosenberg et $\mathrm{al}^{66}$ found a significant reduction in the progression of dementia in Alzheimer's patients taking statins when compared with control subjects $(P=0.03)$.

\section{Parkinson's disease}

Using a mouse model of Parkinson's disease, Ghosh et al ${ }^{67}$ observed protection of dopaminergic neurons, striatal neurotransmitter normalization, and stabilization of motor function in mice treated with simvastatin or pravastatin. Analysis of the US Veterans' Affairs database showed a 54\% reduced incidence of dementia $(P<0.0001)$ and a $49 \%$ reduction in the incidence of newly diagnosed Parkinson's disease in individuals who were taking simvastatin $(P<0.0001) .{ }^{68}$ Additionally, Wahner et $\mathrm{al}^{69}$ found that patients who were on statin therapy for at least five years had a $63 \%$ reduction in the incidence of Parkinson's disease.

\section{Renovascular disorders Glomerulonephritis and renal failure}

By inhibiting signaling pathways that lead to renal inflammation, glomerular scarring, and mesangial proliferation, ${ }^{70}$ statins reduce the systemic production and renal infiltration of T cells, T-helper cells, macrophages, and neutrophils. ${ }^{71}$ Ozsoy et al $^{72}$ studied 31 patients with established glomerulonephritis and proteinuria who were on angiotensin-converting enzyme inhibitor therapy. Adding atorvastatin to their medical regimen conferred a $22 \%$ reduction in proteinuria after six weeks of therapy $(P=0.005)$. The benefits of statin therapy have also been observed in hemodialysis patients, who were shown to require significantly lower erythropoietin administration $(P<0.05)$ for renal failure-associated anemia compared with their untreated counterparts. ${ }^{73}$

\section{Renal transplantation}

Of particular interest are recent studies that have shown statin pleiotropy in patients who have undergone renal transplantation. Pazik et $\mathrm{al}^{74}$ looked at patients with posttransplant glomerulonephritis and found that maintenance immunosuppression with steroid infusions, alkylating agents, or antiproliferatives did not prolong graft survival. However, patients who had a statin added to their medical regimen had a $63 \%$ reduced risk $(P<0.02)$ of graft loss, and when combined with renin-angiotensin-aldosterone system inhibitors, the reduction increased to $76 \%(P<0.008)$.

\section{Contrast-induced nephropathy}

The antioxidant and vascular effects of statins are thought to attenuate the development of contrast-induced nephropathy, a serious complication of radiographic and diagnostic procedures that results from decreased renal medullary blood flow and toxic insult to the renal tubules. ${ }^{75}$ Khanal et $\mathrm{al}^{76}$ looked at 29,409 patients who underwent percutaneous coronary intervention and found that chronic statin therapy prior to intervention was associated with a lower risk of contrast-induced nephropathy $(P<0.0001)$ or renal damage requiring dialysis therapy $(P=0.03)$. Similar findings were reported by Patti et al, ${ }^{77}$ who observed 434 patients undergoing percutaneous coronary intervention and found that preprocedural statin therapy resulted in a reduced incidence of contrast-induced nephropathy $(P<0.0001)$ and a greater postprocedure creatinine clearance compared with placebo $(P<0.0001)$.

\section{Rheumatologic disorders Rheumatoid arthritis}

Via the inhibition and downregulation of proinflammatory cytokines and chemokines, ${ }^{78,79}$ statins have been shown to decrease serum $C$-reactive protein $(P=0.025)$ and tumor necrosis factor-alpha levels $(P=0.012)$ significantly in rheumatoid arthritis patients while improving endothelial function. ${ }^{80}$ Recently, Amital et al ${ }^{81}$ reviewed a large health maintenance organization database and looked at the incidence of newly diagnosed rheumatoid arthritis over a 10 -year period. Statin users had a $40 \%$ reduced risk $(P<0.001)$ of developing rheumatoid arthritis, and their protective value was greater the younger the age of the patient $(P<0.001)$. 


\section{Osteoporosis}

Statins inhibit osteoclast bone resorption and stimulate the production of specific proteins involved in the development of bone and cartilage, ${ }^{82,83}$ thus emerging as a possible therapeutic option for patients with osteoporosis. Tanriverdi et $\mathrm{al}^{84}$ followed 120 hypercholesterolemic postmenopausal women with osteoporosis or osteopenia over a six-month period. Women treated with risedronate and atorvastatin had a twofold increase in bone mineral density at the lumbar spine compared with women treated with risedronate alone $(P<0.05)$. A meta-analysis by Hatzigeorgiou et al ${ }^{85}$ revealed that patients taking statins had a $40 \%$ reduction in hip fractures and improved hip bone mineral density, and statin therapy has also been linked to increased bone mineral density at the femur and femoral neck $(P<0.05){ }^{86}$

\section{Systemic sclerosis}

Statins are hypothesized to reduce endothelial injury and inhibit defective vasculogenesis and vascular fibrosis in patients with systemic sclerosis. ${ }^{87,88}$ Kuwana et al ${ }^{89}$ treated eight systemic sclerosis patients with $10 \mathrm{mg}$ of atorvastatin daily for a total of 24 months and found a reduction in flairs of Raynaud's phenomenon, decreased activation of angiogenic factors, and reduced levels of vascular endothelial activation and injury markers. A separate randomized trial by Abou-Raya et $a 1^{90}$ of 84 patients with systemic sclerosis also showed the benefit of statin therapy, as patients treated with $40 \mathrm{mg}$ of atorvastatin daily developed an average of 1.6 new digital ulcers over a four-month treatment period versus 2.5 in the placebo group $(P=0.003)$.

\section{Miscellaneous disorders Venous thromboembolism}

Circulating lipid molecules appear to affect vascular endothelial and platelet function and may act as procoagulants, thus lipid-lowering with statins may protect against development of venous thromboembolism. ${ }^{91} \mathrm{~A}$ recent meta-analysis ${ }^{92}$ of nearly one million patients from one randomized and nine observational trials who were on statin therapy for cardiovascular risk prevention revealed a $32 \%$ decreased risk of venous thromboembolism $(P<0.05)$, a $41 \%$ decreased risk of deep vein thrombosis $(P<0.05)$, and a $30 \%$ decreased risk of pulmonary embolism $(P<0.05)$. Furthermore, evidence suggests that statins may be of particular benefit in cancer patients, in whom venous thromboembolism and pulmonary embolism are serious sequelae. Khemasuwan et a $\mathrm{a}^{93}$ retrospectively studied 740 patients with solid organ tumors who were hospitalized and placed on a statin, and found a $67 \%$ decreased risk of venous thromboembolism within two months of admission in statin users $(P<0.001)$.

\section{Polycystic ovary syndrome}

A reduction in insulin receptor maturation and inhibition of thecal interstitial cell proliferation are hypothesized to be the pleiotropic mechanisms of statins observed in females suffering from polycystic ovary syndrome. . $^{94,95}$ Sathyapalan et a ${ }^{96}$ studied 40 statin-naïve patients who were placed on 12 weeks of atorvastatin therapy and found significant reductions in testosterone $(P<0.01)$, free androgen index (testosterone/sex hormone binding globulin, $P<0.01$ ), and insulin resistance as measured by the homeostasis model assessment for insulin resistance. A study by Banaszewska et al ${ }^{97}$ compared 48 polycystic ovary syndrome patients on oral contraceptive treatment with patients on oral contraceptive treatment plus simvastatin, and found that adjuvant statin therapy was associated with an additional $12 \%$ reduction in total testosterone $(P<0.004)$, a $23 \%$ reduction in free testosterone $(P=0.006)$, a $3.4 \%$ decreased incidence in hirsutism $(P=0.02)$, and a $39 \%$ reduction in C-reactive protein level $(P=0.006)$ compared with those on oral contraceptive treatment alone.

\section{Macular degeneration}

Statin use has been linked to a $67 \%$ reduction in drusen formation, ${ }^{98}$ which deprives certain areas of the eye of oxygen and nutrients and is associated with the onset of macular degeneration. Choroidal neovascularization, an early symptom of age-related macular degeneration, has also been shown to be inhibited by statins in vitro. ${ }^{99}$ A retrospective study by Wilson et a ${ }^{100}$ of 326 patients with age-related macular degeneration reported a $49 \%$ reduction in the rate of choroidal neovascularization in statin-treated patients $(P=0.01)$, while a case-control study by McGwin et al ${ }^{101}$ found a $70 \%$ risk reduction in newly-diagnosed macular degeneration amongst statin users.

\section{Influenza}

Recent data suggest that statins may confer protection against infectious diseases, including the influenza virus. Kwong et $\mathrm{al}^{102}$ assessed the effects of statin use on hospitalization rates and mortality during the influenza season over a 10-year period using a population-based cohort study of 2.2 million patients. Researchers found an $8 \%$ reduced risk of pneumonia hospitalization and a $16 \%$ reduction in 30-day 
Table 6 Pleiotropic effects of statins in miscellaneous disorders

\begin{tabular}{|c|c|}
\hline Venous & - $32 \% \downarrow$ in noncancer patients \\
\hline thromboembolism ${ }^{92,93}$ & $\begin{array}{l}\text { - } 67 \% \downarrow \text { in those with solid organ tumors } \\
\text { - } 41 \% \downarrow \text { risk of deep vein thrombosis } \\
\text { - } 30 \% \downarrow \text { risk of pulmonary embolism }\end{array}$ \\
\hline $\begin{array}{l}\text { Polycystic ovary } \\
\text { syndrome } \\
96,97\end{array}$ & $\begin{array}{l}\text { - } \downarrow \text { testosterone levels, free androgen index, } \\
\text { insulin resistance, and incidence of hirsutism } \\
\text { - Increases therapeutic effects of oral } \\
\text { contraceptives }\end{array}$ \\
\hline $\begin{array}{l}\text { Macular } \\
\text { degeneration } 98-101\end{array}$ & $\begin{array}{l}-70 \% \downarrow \text { of age-related macular degeneration } \\
\text { - } 67 \% \downarrow \text { drusen formation } \\
\text { - } 49 \% \downarrow \text { choroidal neovascularization }\end{array}$ \\
\hline Influenza ${ }^{102-104}$ & $\begin{array}{l}-8 \% \downarrow \text { risk of hospitalization } \\
\text { - } \downarrow \text { risk of pneumonia, or influenza-related death }\end{array}$ \\
\hline $\begin{array}{l}\text { Infection and } \\
\text { sepsis }^{105-108}\end{array}$ & $\begin{array}{l}-\downarrow 30 \text {-day, inhospital, bacteremia, sepsis, and } \\
\text { mixed infection-related mortality } \\
\text { - } 35 \% \downarrow \text { incidence of severe sepsis in intensive } \\
\text { care unit patients } \\
\text { - } \downarrow \text { risk of Candida infections in hospitalized } \\
\text { diabetics }\end{array}$ \\
\hline
\end{tabular}

pneumonia mortality. A separate matched cohort study of 76,232 patients by Frost et a ${ }^{103}$ found a $40 \%$ reduction in the risk of pneumonia or influenza-related death in moderatedose statin users, and a recent study ${ }^{104}$ presented at the 2010 Infectious Disease Society of America annual meeting showed a $54 \%$ reduced risk of death amongst statin users hospitalized for influenza.

\section{Infection and sepsis}

A recent meta-analysis of 20 studies analyzed the effects of statins on mortality from infection and sepsis. Statin therapy was associated with a $39 \%$ reduction in 30-day mortality, a $62 \%$ reduction in the inhospital mortality, a $37 \%$ reduction in pneumonia-related mortality, a $77 \%$ reduction in bacteremiarelated mortality, a $60 \%$ reduction in sepsis-related mortality, and a $50 \%$ reduction in mixed infection-related mortality. ${ }^{105}$ Dobesh et al ${ }^{106}$ retrospectively assessed the link between statin therapy and severe sepsis in 188 intensive care unit patients and found a $35 \%$ reduction $(P=0.04)$ compared with nonusers having APACHE II scores of $\geq 24$. Finally, statins have been associated with reduced mortality in solid-organ transplant recipients who developed bacteremia ${ }^{107}$ and a decreased risk of Candida infection in hospitalized diabetics $(P=0.031),{ }^{108}$ indicating that statins may be beneficial in immunocompromised patients or those at risk for opportunistic infections (Table 6).

\section{Conclusion}

The major limitations regarding the current literature on the pleiotropic effects of statins are that the majority of studies were observational in nature, and usually small in size. There is a lack of data corroboration via large, randomized, placebo-controlled trials. While current evidence is not definitive, there is great potential for the use of statins as adjuvant therapy in a wide range of disease processes and is a worthwhile topic for researchers and clinicians alike.

\section{Disclosure}

The authors report no conflicts of interest in this work.

\section{References}

1. Pignone M, Phillips C, Mulrow C. Use of lipid lowering drugs for primary prevention of coronary heart disease: Meta-analysis of randomized trials. BMJ. 2000;321:983-985.

2. Tonkin A, Aylward P, Colquhoun D, et al. Prevention of cardiovascular events and death with pravastatin in patients with coronary heart disease and a broad range of initial cholesterol levels. The Long-Term Intervention with Pravastatin in Ischaemic Disease (LIPID) study group. N Engl J Med. 1998;339:1349-1357.

3. Endres M. Statins and stroke. J Cereb Blood Flow Metab. 2005;25: 1093-1110.

4. Liao JK. Beyond lipid lowering: The role of statins in vascular protection. Int J Cardiol. 2002;86:5-18.

5. Li J, Li JJ, He JG, Nan JL, Guo YL, Xiong CM. Atorvastatin decreases $\mathrm{C}$-reactive protein-induced inflammatory response in pulmonary artery smooth muscle cells by inhibiting nuclear factor-kappa B pathway. Cardiovasc Ther. 2010;28:8-14.

6. Tandon V, Bano G, Khajuria V, Parihar A, Gupta S. Pleiotropic effects of statins. Indian J Pharmacol. 2005;37:77-85.

7. Cleland JG, McMurray JJ, Kjekshus J, et al. Plasma concentration of amino-terminal pro-brain natriuretic peptide in chronic heart failure: Prediction of cardiovascular events and interaction with the effects of rosuvastatin. A report from CORONA (Controlled Rosuvastatin Multinational Trial in Heart Failure). J Am Coll Cardiol. 2009;54:1850-1859.

8. Barrios V, Escobar E. Rosuvastatin along the cardiovascular continuum: From JUPITER to AURORA. Expert Rev Cardiovasc Ther. 2009;7:1317-1327.

9. McMurray JJ, Kjekshus J, Gullestad L, et al. Effects of statin therapy according to plasma high-sensitivity C-reactive protein concentration in the controlled rosuvastatin multinational trial in heart failure (CORONA): A retrospective analysis. Circulation. 2009;120: 2188-2196.

10. Kjeshkus J, Apretei E, Barrios V, et al. Rosuvastatin in older patients with systolic heart failure. N Engl J Med. 2007;357:2248-22461.

11. Okazaki H. Statin prevents structural and electrical remodeling in rat hypertensive heart failure induced by chronic inhibition of NO synthesis. Circulation. 2007;116 Suppl:II-140.

12. Kumagai K, Nakashima H, Saku K. The HMG-CoA reductase inhibitor atorvastatin prevents atrial fibrillation by inhibiting inflammation in a canine sterile pericarditis model. Cardiovasc Res. 2004;62:105-111.

13. Young-Xu Y, Jabbour S, Goldberg R, et al. Usefulness of statin drugs in protecting against atrial fibrillation in patients with coronary artery disease. Am J Cardiol. 2003;92:1379-1383.

14. Kulik A, Singh JP, Levin R, Avorn J, Choudhry NK. Association between statin use and the incidence of atrial fibrillation following hospitalization for coronary artery disease. Am J Cardiol. 2010;105:1655-1660.

15. Siu C, Lau C, Tse H. Prevention of atrial fibrillation recurrence by statin therapy in patients with lone atrial fibrillation after successful cardioversion. Am J Cardiol. 2003;92:1343-1345.

16. Sun YF, Mei YQ, Ji Q, et al. Effect of atorvastatin on postoperative atrial fibrillation in patients undergoing coronary artery bypass grafting. Zhonghua Yi Xue Za Zhi. 2009;89:2988-2991. Chinese. 
17. Vedre A, Gurm H, Froehlich J, et al. Impact of prior statin therapy on arrhythmic events in patients with acute coronary syndromes (from the Global Registry of Acute Coronary Events [GRACE]). Am J Cardiol. 2009;104:1613-1617.

18. Chiu JH, Abdelhadi RH, Chung MK, et al. Effect of statin therapy on risk of ventricular arrhythmia among patients with coronary artery disease and an implantable cardioverter-defibrillator. Am J Cardiol. 2005;95:490-491.

19. Vyas AK, Guo H, Moss AJ, et al. Reduction in ventricular tachyarrhythmias with statins in the Multicenter Automatic Defibrillator Implantation Trial (MADIT) II. J Am Coll Cardiol. 2006;47:769-773.

20. Kim JS, Kim J, Choi D, et al. Efficacy of high-dose atorvastatin loading before primary percutaneous coronary intervention in ST-segment elevation myocardial infarction: The STATIN STEMI trial. JACC Cardiovasc Interv. 2010;3:332-339.

21. Pasceri V, Patti G, Nusca A, Pristipino C, Richichi G, Di Sciascio G. Randomized trial of atorvastatin for reduction of myocardial damage during coronary intervention: Results from the ARMYDA (Atorvastatin for Reduction of MYocardial Damage during Angioplasty) trial. Circulation. 2004;110:674-678.

22. Cay S, Cagirci G, Sen N, Balbay Y, Durmaz T, Aydogdu S. Prevention of peri-procedural myocardial injury using a single high loading dose of rosuvastatin. Cardiovasc Drugs Ther. 2010;24:41-47.

23. Yun KH, Oh SK, Rhee SJ, Yoo NJ, Kim NH, Jeong JW. 12-month follow-up results of high dose rosuvastatin loading before percutaneous coronary intervention in patients with acute coronary syndrome. Int $J$ Cardiol. 2011;146:68-72.

24. Ridker PM, Morrow DA, Rose LM, Rifai N, Cannon CP, Braunwald E. Relative efficacy of atorvastatin $80 \mathrm{mg}$ and pravastatin $40 \mathrm{mg}$ in achieving the dual goals of low-density lipoprotein cholesterol $<70 \mathrm{mg} / \mathrm{dl}$ and C-reactive protein $<2 \mathrm{mg} / \mathrm{l}$ : An analysis of the PROVE-IT TIMI-22 trial. J Am Coll Cardiol. 2005;45:1644-1648.

25. Gibson CM, Pride YB, Hochberg CP, Sloan S, Sabatine MS, Cannon CP. Effect of intensive statin therapy on clinical outcomes among patients undergoing percutaneous coronary intervention for acute coronary syndrome. PCI-PROVE IT: A PROVE IT-TIMI 22 (Pravastatin or Atorvastatin Evaluation and Infection Therapy-Thrombolysis In Myocardial Infarction 22) substudy. J Am Coll Cardiol. 2009;54:2290-2295.

26. Di Sciascio G, Patti G, Pasceri V, Gaspardone A, Colonna G, Montinaro A. Efficacy of atorvastatin reload in patients on chronic statin therapy undergoing percutaneous coronary intervention: Results from the ARMYDA-RECAPTURE (Atorvastatin for Reduction of MYocardial Damage during Angioplasty) randomized trial. J Am Coll Cardiol. 2009;54:558-565.

27. Novaro GM, Tiong IY, Pearce GL, et al. Effect of hydroxymethylglutaryl coenzyme A reductase inhibitors on the progression of calcific aortic stenosis. Circulation. 2001;104:2205-2209.

28. Aronow WS, Ahn C, Kronzon I, et al. Association of coronary risk factors and use of statins with progression of mild valvular stenosis in older persons. Am J Cardiol. 2001;88:693-695.

29. Bellamy MF, Pellikka PA, Klarich KW, et al. Association of cholesterol levels, hydroxymethylglutaryl coenzyme A reductase inhibitor treatment, and progression of aortic stenosis in the community. J Am Coll Cardiol. 2002;40:1723-1730.

30. Moura LM, Ramos SF, Zamorano JL, et al. Rosuvastatin affecting aortic valve endothelium to slow the progression of aortic stenosis. J Am Coll Cardiol. 2007;49:554-561.

31. Pagovich O, Wang E, Lee-Wong M. Statins may improve asthma. J Allergy Clin Immunol. 2010;125:Abstr 178.

32. Stanek E, Aubert R, Xia F, et al. Statin exposure reduces the risk of asthma-related hospitalizations and emergency room visits in asthmatic patients on inhaled corticosteroids. J Allergy Clin Immunol. 2009; 123:Abstr 238

33. Blamoun AI, Batty GN, DeBari VA, Rashid AO, Sheikh M, Khan MA. Statins may reduce episodes of exacerbation and the requirement for intubation in patients with COPD: Evidence from a retrospective cohort study. Int J Clin Pract. 2008;62:1373-1378.
34. Mortensen EM, Copeland LA, Pugh MJ, et al. Impact of statins and ACE inhibitors on mortality after COPD exacerbations. Respir Res. 2009;10:1-9.

35. Alexeeff SE, Litonjua AA, Sparrow D, Vokonas PS, Schwartz J. Statin use reduces decline in lung function: VA Normative Aging Study. Am J Respir Crit Care Med. 2007;176:742-747.

36. Keddissi JI, Younis WG, Chbeir EA, Daher NN, Dernaika TA, Kinasewitz GT. The use of statins and lung function in current and former smokers. Chest. 2007;132:1764-1771.

37. Parikh A, Childress C, Deitrick K, Lin Q, Rukstalis D, Yang W. Statin-induced autophagy by inhibition of geranylgeranyl biosynthesis in prostate cancer PC3 cells. Prostate. 2010;70:971-981.

38. Katz MS, Carroll PR, Cowan JE, Chan JM, D’Amico AV. Association of statin and nonsteroidal anti-inflammatory drug use with prostate cancer outcomes: Results from CaPSURE. BJU Int. 2010;106: 627-632.

39. Gutt R, Tolnaar N, Kunnavakkam R, Karrison T, Weichselbaum RR, Liauw SL. Statin use and the risk of prostate cancer recurrence in men treated with radiation therapy. J Clin Oncol. 2010;28;2653-2659.

40. Banez LL, Klink JC, Jayachandran J, et al. Association between statins and prostate tumor inflammatory infiltrate in men undergoing radical prostactectomy. Cancer Epidemiol Biomarkers Prev. 2010;19: $722-728$.

41. Cho SJ, Kim JS, Kim JM, Lee YJ, Jung JS, Song IS. Simvastatin induces apoptosis in human colon cancer cells and in tumor xenografts, and attenuates colitis-associated colon cancer in mice. Int $J$ Cancer. 2008;123:951-957.

42. Kaneko R, Tsuji N, Asanuma K, Tanebe H, Kobayashi D, Watanabe N. Survivin down-regulation plays a crucial role in 3-hydroxy3-methylglutaryl coenzyme A reductase inhibitor-induced apoptosis in cancer. J Biol Chem. 2007;282:19273-19281.

43. Agarwal B, Bhendwal S, Halmos B, Moss SF, Ramey WG, Holt PR. Lovastatin augments apoptosis induced by chemotherapeutic agents in colon cancer cells. Clin Cancer Res. 1999;5:2223-2229.

44. Poynter JN, Gruber SB, Higgins PD, et al. Statins and the risk of colorectal cancer. N Engl J Med. 2005;352:2184-2192.

45. Coogan PF, Smith J, Rosenberg L. Statin use and risk of colorectal cancer. J Natl Cancer Inst. 2007;99:32-40.

46. Siddiqui AA, Nazario H, Mahgoub A, Pandove S, Cipher D, Spechler SJ. The long-term use of statins is associated with a decreased incidence of adenomatous colon polyps. Digestion. 2009;79:17-22.

47. Khurana V, Bejjanki HR, Caldito G, Owens MW. Statins reduce the risk of lung cancer in humans: A large case-control study of US veterans. Chest. 2007;131:1282-1288.

48. Khurana V, Sheth A, Caldito G, Barkin JS. Statins reduce the risk of pancreatic cancer in humans: A case-control study of half a million veterans. Pancreas. 2007;34:260-265.

49. Khurana V, Caldito G, Ankem M. Statins might reduce the risk of renal cell carcinoma in humans: A case-control study of 500,000 veterans. Urology. 2008;71:118-122.

50. Everett BM, Glynn RJ, MacFadyen JG, Ridker PM. Rosuvastatin in the prevention of stroke among men and women with elevated levels of C-reactive protein: Justification for the use of statins in prevention: An Intervention Trial Evaluating Rosuvastatin (JUPITER). Circulation 2010;121:143-150.

51. Sugawara T, Ayer R, Zhang JH. Role of statins in cerebral vasospasm. Acta Neurochir Suppl. 2008;104:287-290.

52. Lapchak PA, Han MK. The 3-hydroxy-3-methyglutaryl A reductase inhibitor simvastatin reduces thrombolytic-induced intracerebral hemorrhage in embolized rabbits. Brain Res. 2009;1303:144-150.

53. Sterzer P, Meintzschel F, Rösler A, Lanfermann H, Steinmetz H, Sitzer M. Pravastatin improves cerebral vasomotor reactivity in patients with subcortical small-vessel disease. Stroke. 2001;32: 2817-2820.

54. Amarenco P, Labreuche J. Lipid management in the prevention of stroke: Review and updated meta-analysis of statins for stroke prevention. Lancet Neurol. 2009;8:453-463. 
55. Naval NS, Abdelhak TA, Zeballos P, Urrunaga N, Mirski MA, Carhuapoma JR. Prior statin use reduces mortality in intracerebral hemorrhage. Neurocrit Care. 2008;8:6-12.

56. Sillberg VA, Wells GA, Perry JJ. Do statins improve outcomes and reduce the incidence of vasospasm after aneurysmal subarachnoid hemorrhage: A meta-analysis. Stroke. 2008;39:2622-2626.

57. Markovic-Plese S, Singh AK, Singh I. Therapeutic potential of statins in multiple sclerosis: Immune modulation, neuroprotection and neurorepair. Future Neurol. 2008;3:153-167.

58. Weber MS, Zamvil SS. Statins and demyelination. Curr Top Microbiol Immunol. 2008;318:313-324.

59. Cooreale J, Villa A. The blood-brain-barrier in multiple sclerosis: Functional roles and therapeutic monitoring. Autoimmunity. 2007;40: $148-160$.

60. Ifergan I, Wosik K, Cayrol R, et al. Statins reduce human blood-brain barrier permeability and restrict leukocyte migration: Relevance to multiple sclerosis. Ann Neurol. 2006;60:45-55.

61. Vollmer T, Key L, Durkalski V, et al. Oral simvastatin treatment in relapsing-remitting multiple sclerosis. Lancet. 2004;363:1607-1608.

62. Paul F, Waiczies S, Wuerfel J, et al. Oral high-dose atorvastatin treatment in relapsing-remitting multiple sclerosis. PLoS One. 2008;3:e1928.

63. Wang Q, Yan J, Chen X, et al. Statins: Multiple neuroprotective mechanisms in neurodegenerative diseases. Exper Neurol. April 18, 2010. [Epub ahead of print].

64. Harris JR, Milton NG. Cholesterol in Alzheimer's disease and other amyloidogenic disorders. Subcell Biochem. 2010;51:47-75.

65. Li G, Shofer JB, Rhew IC, et al. Age-varying association between statin use and incident Alzheimer's disease. J Am Geriatr Soc. 2010; 58:1311-1317.

66. Rosenberg PB, Mielke MM, Tschanz J, et al. Effects of cardiovascular medications on rate of functional decline in Alzheimer disease. $\mathrm{Am} \mathrm{J}$ Geriatr Psychiatry. 2008;16:883-892.

67. Ghosh A, Roy A, Matras J, Brahmachari S, Gendelman HE, Pahan K. Simvastatin inhibits the activation of $\mathrm{p} 21$ ras and prevents the loss of dopaminergic neurons in a mouse model of Parkinson's disease. J Neurosci. 2009;29:13543-13546.

68. Wolozin B, Wang SW, Li N, Lee A, Lee TA, Kazis LE. Simvastatin is associated with a reduced incidence of dementia and Parkinson's disease. BMC Med. 2007;5:1-11.

69. Wahner AD, Bronstein JM, Bordelon YM, Ritz B. Statin use and the risk of Parkinson disease. Neurology. 2008;70:1418-1422.

70. Kostapanos MS, Liberopoulos EN, Elisaf MS. Statin pleiotropy against renal injury. J Cardiometab Syndr. 2009;4:E4-E9.

71. Eller P, Eller K, Wolf AM, et al. Atorvastatin attenuates murine antiglomerular basement membrane glomerulonephritis. Kidney Int. 2010; $77: 428-435$

72. Ozsoy RC, Koopman MG, Kastlelein JJ, Arisz L. The acute effect of atorvastatin on proteinuria in patients with chronic glomerulonephritis. Clin Nephrol. 2005;63:245-249.

73. Tangdhanakanond K, Raja R. Effects of statins on erythropoieten responsiveness in type-2 diabetic versus non-diabetic hemodialysis patients. Clin Nephrol. 2010;73:1-6.

74. Pazik J, Ostrowska J, Lewandowski Z, et al. Renin-angiotensinaldosterone system inhibitors and statins prolong graft survival in post-transplant glomerulonephritis. Ann Transplant. 2008;13:41-45.

75. Kandzari DE, Rebeiz AG, Wang A, Sketch MH Jr. Contrast nephropathy: An evidence-based approach to prevention. Am J Cardiovasc Drugs. 2003;3:395-405.

76. Khanal S, Attallah N, Smith DE, et al. Statin therapy reduces contrastinduced nephropathy: An analysis of contemporary percutaneous interventions. Am J Med. 2005;118:843-849.

77. Patti G, Nusca A, Chello M, et al. Usefulness of statin pretreatment to prevent contrast-induced nephropathy and to improve long-term outcome in patients undergoing percutaneous coronary intervention. Am J Cardiol. 2008;101:279-285.
78. Blaschke S, Viereck V, Schwarz G, Klinger HM, Guerluek S, Müller GA. Anti-inflammatory effects of atorvastatin on peripheral blood mononuclear cells and synovial fibroblasts in rheumatoid arthritis. Scand $J$ Rheumatol. 2009;38:235-239.

79. Lazzerini PE, Lorenzini S, Selvi E, et al. Simvastatin inhibits cytokine production and nuclear factor-k B activation in interleukin 1-beta stimulated synoviocytes from rheumatoid arthritis patients. Clin Exp Rheumatol. 2007;25;696-700.

80. Tikiz C, Utuk O, Pirildar T, et al. Effects of angiotensin-converting enzyme inhibition and statin treatment on inflammatory markers and endothelial functions in patients with long-term rheumatoid arthritis. J Rheumatol. 2005;32:2095-2101.

81. Amital H, Chodick G, Shalem Y, Shalev V. HMG-CoA reductase inhibitors (statins) provide primary prevention for rheumatoid arthritis. Arthritis Rheum. 2009;60 Suppl 10:1174.

82. Bauer DC. HMG CoA reductase inhibitors and the skeleton: A comprehensive review. Osteoporos Int. 2003;14:273-282.

83. Majima T, Komatsu Y, Fukao A, Ninomiya K, Matsumura T, Nakao K. Short term effects of atorvastatin on bone turnover in male patients with hypercholesterolemia. Endocr J. 2007;54:145-151.

84. Tanriverdi HA, Barut A, Sarikaya S. Statins have additive effects to vertebral bone mineral density in combination with risedronate in hypercholesterolemic postmenopausal women. Eur J Obstet Gynecol Reprod Biol. 2005;120:63-68.

85. Hatzigeorgiou C, Jackson JL. Hydroxymethylglutaryl-coenzyme A reductase inhibitors and osteoporosis: A meta-analysis. Osteoporos Int. 2005;16:990-998.

86. Montagnani A, Gonnelli S, Cepollaro C, et al. Effect of simvastatin treatment on bone mineral density and bone turnover in hypercholesterolemic postmenopausal women: A 1-year longitudinal study. Bone. 2003;32: $427-433$.

87. Louneva N, Huaman G, Fertala J, Jiménez SA. Inhibition of systemic sclerosis dermal fibroblast type I collagen production and gene expression by simvastatin. Arthritis Rheum. 2006;54:1298-1308.

88. Kuwana M. Potential benefit of statins for vascular disease in systemic sclerosis. Curr Opin Rheumatol. 2006;18:594-600.

89. Kuwana M, Okazaki Y, Kaburaki J. Long-term beneficial effects of statins on vascular manifestations in patients with systemic sclerosis. Mod Rheumatol. 2009;19:530-535.

90. Abou-Raya A, Abou-Raya S, Helmii M. Statins: Potentially useful in therapy of systemic sclerosis-related Raynaud's phenomenon and digital ulcers. J Rheumatol. 2009;35:1801-1808.

91. Ray JG. Dyslipidemia, statins, and venous thromboembolism: A potential risk factor and a potential treatment. Curr Opin Pulm Med. 2003;9:378-384.

92. Agarwal V, Bhardwaj A, Tongbram V, et al. What effect do statins have on the development of venous thromboembolism? A comprehensive meta-analysis of over 900,000 patients. Int J Clin Pract. 2010;64: 1375-1383.

93. Khemasuwan D, Divietro ML, Tangdhanakanond K, Pomerantz SC, Eiger G. Statins decrease the occurrence of venous thromboembolism in patients with cancer. Am J Med. 2010;123:60-65.

94. Kodaman PH, Duleba AJ. Statins in the treatment of polycystic ovary syndrome. Semin Reprod Med. 2008;26:127-138.

95. Rzepczynska IJ, Piotrowski PC, Wong D, Cress AB, Villanueva J, Duleba AJ. Role of isoprenylation in simvastatin-induced inhibition of ovarian theca-interstitial growth in the rat. Biol Reprod. 2009;81: $850-855$.

96. Sathyapalan T, Kilpatrick ES, Coady AM, Atkin SL. The effect of atorvastatin in patients with polycystic ovary syndrome: A randomized double-blind placebo-controlled study. J Clin Endocrinol Metab. 2009;94:103-108.

97. Banaszewska B, Pawelczyk L, Spaczynski R, Dziura J, Duleba AJ. Effects of simvastatin and oral contraceptive agent on polycystic ovary syndrome: Prospective, randomized, crossover trial. J Clin Endocrinol Metab. 2007;92:456-461. 
98. Tan JS, Mitchell P, Rochtchina E, Wang JJ. Statins and the long-term risk of incident age-related macular degeneration: The Blue Mountains Eye Study. Am J Ophthalmol. 2007;143:685-687.

99. Sagara N, Kawaji T, Takano A, et al. Effect of pitavistatin on experimental choroidal neovascularization in rats. Exp Eye Res. 2007; 84:1074-1080.

100. Wilson HL, Schwartz DM, Bhatt HR, McCulloch CE, Duncan JL. Statin and aspirin therapy are associated with decreased rates of choroidal neovascularization among patients with age-related macular degeneration. Am J Ophthalmol. 2004;137:615-624.

101. McGwin G Jr, Owsley C, Curcio CA, Crain RJ. The association between statin use and age related maculopathy. Br J Ophthalmol. 2003;87:1121-1125.

102. Kwong JC, Li P, Redelmeier DA. Influenza morbidity and mortality in elderly patients receiving statins: A cohort study. PLoS One. 2009; 4:e8087.

103. Frost FJ, Peterson H, Tollestrup K, Skipper B. Influenza and COPD mortality protection as pleiotropic, dose-dependent effects of statins. Chest. 2007;131:1006-1012.
104. Vandermeer M, Thomas A, Kamimoto L, et al. Role of statins in preventing death among patients hospitalized with lab-confirmed influenza infections. Infectious Diseases Society of America 47th annual meeting, 2009. Boston, MA, October 29-November 1, 2009:Abstr 706.

105. Janda S, Young A, Fitzgerald JM, Etminan M, Swiston J. The effect of statins on mortality from severe infections and sepsis: A systematic review and meta-analysis. J Crit Care. 2010;25:656.e7-656.e22.

106. Dobesh PP, Klepser DG, McGuire TR, Morgan CW, Olsen KM. Reduction in mortality associated with statin therapy in patients with severe sepsis. Pharmacotherapy. 2009;29:621-630.

107. Hsu J, Andres DR, Knasinksi V, Pirsch J, Safdar N. Statins are associated with improved outcomes of bloodstream infection in solidorgan transplant recipients. Eur J Clin Microbiol Infect Dis. 2009;28: 1343-1351

108. Spanakis I, Kourkoumpetis T, Peleg A, Livanis G, Mylonakis E. The impact of statin therapy on candida colonization or infection among patients with diabetes type 2. American Association of Clinical Endocrinologists 19th annual meeting, 2010. Boston, MA, April 21-25, 2010:Abstr 401.
International Journal of General Medicine

\section{Publish your work in this journal}

The International Journal of General Medicine is an international peer-reviewed open-access journal that focuses on general and internal medicine, pathogenesis, epidemiology, diagnosis, monitoring and treatment protocols. The journal is characterized by the rapid reporting of reviews, original research and clinical studies across all disease areas.

\section{Dovepress}

A key focus is the elucidation of disease processes and management protocols resulting in improved outcomes for the patient.The manuscript management system is completely online and includes a very quick and fair peer-review system. Visit http://www.dovepress.com/ testimonials.php to read real quotes from published authors.

Submit your manuscript here: http://www.dovepress.com/international-journal-of-general-medicine-journal 